\title{
Inflammation generating potential of long and short fibre amosite asbestos samples
}

\author{
K DONALDSON, G M BROWN, D M BROWN, R E BOLTON, J M G DAVIS \\ From the Institute of Occupational Medicine, Edinburgh EH8 9SU, UK
}

\begin{abstract}
Previous studies have shown that long thin asbestos fibres are more pathogenic in in vivo and more active in in vitro assays than short fibre samples. In the present study a long fibre amosite asbestos sample and a short fibre sample prepared from it were tested for ability to cause inflammation in the peritoneal cavity of the mouse; a UICC sample intermediate in fibre size and an inert compact dust, $\mathrm{TiO}_{2}$, were also tested. The ability of the dust samples to cause inflammation, as judged by macrophage and neutrophil recruitment, was ranked in the order long fibre $>$ UICC $>$ short fibre $>\mathrm{TiO}_{2}$. Ability of amosite samples to cause inflammation was therefore related to the proportion of long fibres. The enhanced ability of long fibres to cause inflammation and cause macrophage activation is probably a key factor in the ability of long fibres to cause pulmonary fibrosis and may also be important in fibre carcinogenesis.
\end{abstract}

Inhalation of asbestos dust is associated with the development of interstitial pulmonary fibrosis and pulmonary neoplasia.' Experimental studies have shown, however, that not all asbestos samples are imbued with the same potential to cause lung disease. The shape of the fibres is one factor of major importance in this phenomenon and has been extensively studied (see review ${ }^{2}$ ) showing that long thin fibres are more pathogenic than short fibres. Studies from our own laboratory have recently shown that long amosite asbestos fibres, administered by inhalation, are substantially more pathogenic than a short fibre sample prepared from the long fibres and having essentially the same crystallinity and elemental composition. ${ }^{3}$ The in vivo findings on the pathogenicity of long fires have been, in general, supported by in vitro studies showing that long fibres are most active in short term assays. ${ }^{4}$

Inflammatory responses in the lung parenchyma, while an important defence mechanism in normal circumstances, is considered to be an important arbiter of tissue damage, ${ }^{5}$ leading to alveolar destruction or fibrosis if the inflammation persists. ${ }^{67}$ The inflammatory potential of mineral dusts is therefore likely to be an important correlate of their pathogenic potential. $^{8}$

Recent work from our laboratory has described an assay of the ability of mineral dust to cause inflamma-

Accepted 21 March 1988 tion in vivo ${ }^{9}$ and differences in pathogenicity of long and short fibre amosite samples. ${ }^{3}$

The present study brings these together and seeks to examine the inflammation generating potential of the long and short fibre amosite samples to determine whether this correlates with the ability to cause damage to rat lungs as previously described. ${ }^{2}$

\section{Materials and methods}

\section{DUSTS}

The titanium dioxide was the rutile form supplied by Tioxide Limited (Stockton-on-Tees).

The long fibre amosite comprised a batch of commercially available, milled South African amosite. This sample was generated as a cloud in an exposure chamber (for details see ref 3 ) and the airborne fibres were found to have a size distribution substantially longer than that of the standard UICC amosite which we have used previously. ${ }^{10}$ The long fibre sample used in the present study was collected from the chamber air on to filters. Details of preparation of the short fibre amosite samples have also been given previously. ${ }^{3}$ Briefly, a quantity of the bulk long fibre sample described above was ground in a ceramic ball mill and sedimented in water; comprehensive analysis of the final sample showed no loss of crystallinity and an elemental composition close to the parent long amosite sample. Details of preparation of the UICC amosite sample have been given previously." 


\section{CHARACTERISATION OF THE AMOSITE ASBESTOS SAMPLES}

Long and short fibre amosite were characterised by collecting airborne samples of the dust in exposure chambers on to membrane filters. Fibres $>0.4 \mu \mathrm{m}$ in length and with an aspect ratio $>3: 1$ were sized by scanning electron microscopy at a magnification of $\times 10000$. The UICC amosite sample was collected and sized as part of an earlier study. ${ }^{10}$ Once again the dust was collected from a cloud in an exposure chamber on to membrane filters and sized by scanning electron microscopy, but in this case only fibres longer than $0.6 \mu \mathrm{m}$ were included in the count.

\section{ANIMALS}

Syngenic, male C57B16 mice, 10-12 weeks of age at the time of injection, were used throughout.

\section{INJECTION OF DUSTS}

Dusts were suspended in sterile phosphate buffered saline (Gibco; Paisley) such that $0.5 \mathrm{ml}$ contained 50 , 500 , or $2500 \mu \mathrm{g}$; in addition long and short amosite were injected at $5 \mu \mathrm{g}$. Groups of three mice were then injected intraperitoneally with $0.5 \mathrm{ml}$ of suspended dust.

\section{PERITONEAL LAVAGE}

The leucocyte population of the peritoneal cavity was obtained by lavaging with three sequential injections of $2 \mathrm{ml}$ of PBS containing $10 \mathrm{U} / \mathrm{ml}$ of heparin. A total volume of $5 \mathrm{ml}$ was generally retrieved and the cells were kept on ice in plastic tubes.

\section{CELL COUNTS}

The total cell number retrieved from each mouse was obtained by dilution and counting in a Neubauer chamber. The proportion of each cell type was obtained from cytocentrifuge smears stained with Diff-Quik (Merz-dade, Dudingen, Switzerland). The percentage of each cell type and total numbers were used to calculate the total number of macrophages and neutrophils; other cell types were present at low levels $(<10 \%)$.

\section{MACROPHAGE SPREADING ASSAY}

The activational status of the macrophages was assessed by measuring the ability of the cells to spread on glass for one hour. The method used was that described previously ${ }^{12}$; $10^{5}$ cells in $100 \mu \mathrm{l}$ of RPMI $1640+10 \%$ fetal calf serum (Gibco; Paisley) were placed on $6 \times 22 \mathrm{~mm}$ coverslips and incubated at $37^{\circ} \mathrm{C}$ for one hour. The maximum diameter of 200 Diff-Quik stained macrophages was assessed using a digitising board interfaced with a personal computer and a light microscope. ${ }^{12}$

\section{STATISTICS}

Data were examined by analysis of variance and differences in the means of treatment groups were examined for statistical significance using a $t$ test appropriate for populations with different variances. ${ }^{13}$

\section{Results}

\section{DUST SAMPLES}

The titanium dioxide sample was an isometric dust of $2.5 \mu \mathrm{m}$ median volume diameter. The amosite samples used differed in their size distribution. As shown in figs 1 and 2, the short and long fibre samples had similar diameters but the length distributions differed considerably. Thus the percentage of fibres $>10 \mu \mathrm{m}$ was $0 \cdot 1-0.2 \%$ in the short fibre sample but $10-12 \%$ in the long fibre sample. The UICC sample, which was fibre sized according to slightly different rules (see methods) comprised $2-3 \%$ fibres $>10 \mu \mathrm{m}^{10}$ and so lay midway between the long and short in terms of length distribution; the UICC sample was similar in diameter to the long and short fibre sample. ${ }^{10}$

\section{GENERATION OF INFLAMMATION IN THE MOUSE PERITONEAL CAVITY}

\section{Control}

In preliminary studies we found that the peritonea cavity of control mice injected with saline alone yielded $6.76 \times 10^{6} \pm 0.86$ macrophages and $0.06 \times 10^{6} \pm 0.05$ neutrophils two days after injec-

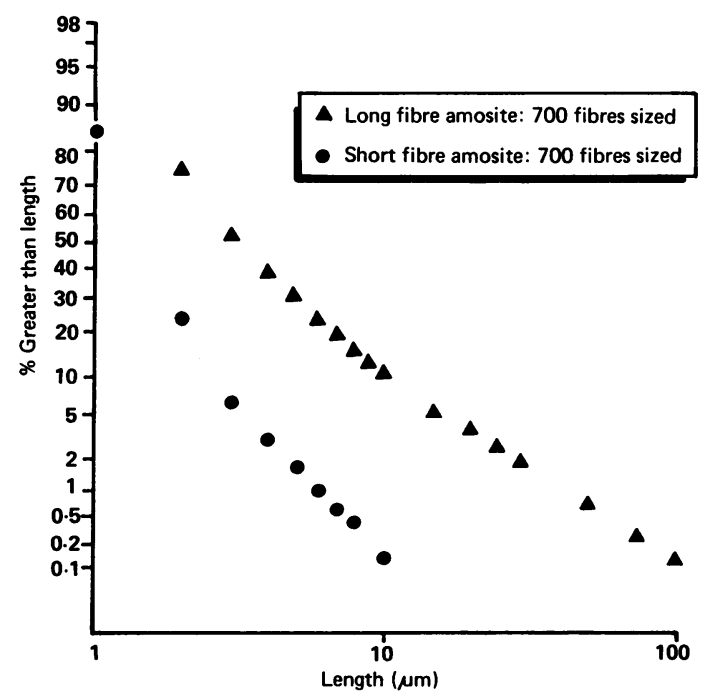

Fig 1 Length distribution of long and short fibre amosite samples. (SEM sizing: $10000 \times$ magnification. Fibres longer than $0.4 \mu \mathrm{m}$ diameter less than $3 \mu \mathrm{m}$ and aspect ratio greater than 3 to 1.) 


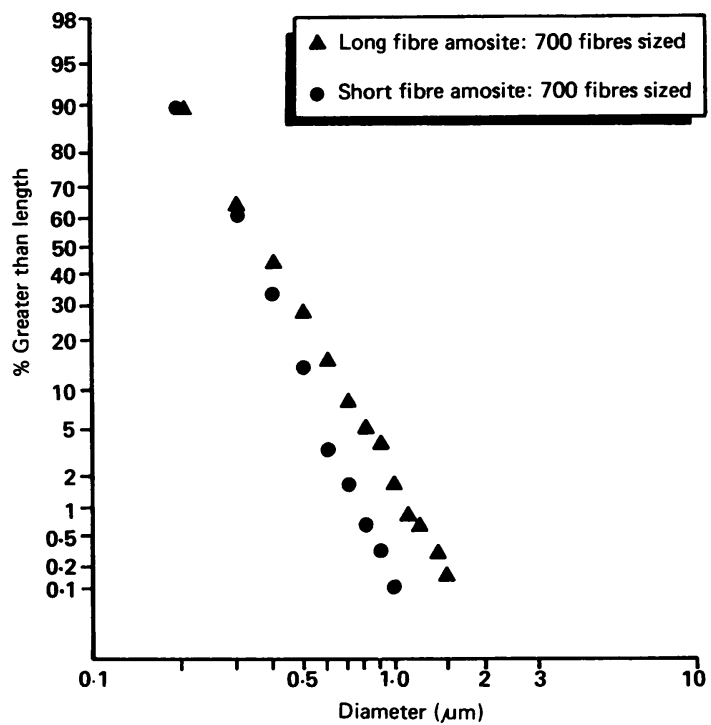

Fig 2 Diameter distribution of long and short fibre amosite samples. (SEM sizing as in fig 1.)

tion. These figures are similar to those found after injections of titanium dioxide which is normally considered to be an innocuous dust. For this reason titanium dioxide was used as a negative control in these studies and the inflammatory response of the three amosite samples was compared with this.

\section{Inflammatory cell recruitment in response to dust}

The inflammatory cell recruitment caused by the different dust samples is shown graphically in figs 3 and 4 ; the statistical significance of comparisons between dusts are shown in tables 1 and 2 .

The pattern of response found consistently with virtually all doses and times was that $\mathrm{TiO}_{2}$ caused least response followed by short amosite whose activity was greater than $\mathrm{TiO}_{2}$ but still was not substantial even at the higher dose. The UICC amosite was more active than short, and long fibre amosite caused, by far, the greatest degree of inflammation.

Amosite samples compared with $\mathrm{TiO}_{2}$

The tables show that, on day 4 , in $13 / 18$ of the comparisons there were no differences between $\mathrm{TiO}_{2}$ and any amosite sample in terms of macrophage response. All, except one, of the exceptions occurred with the middle $(500 \mu \mathrm{g})$ dose. On day 2 however, particularly with UICC v $\mathrm{TiO}_{2}$ and long $\mathrm{v} \mathrm{TiO}_{2}$ the asbestos samples caused significantly more macrophage recruitment (significant differences in 12/18 of comparisons). The neutrophil response tended to be more sensitive with significant increases in numbers with short and UICC compared with $\mathrm{TiO}_{2}$ in 8/12

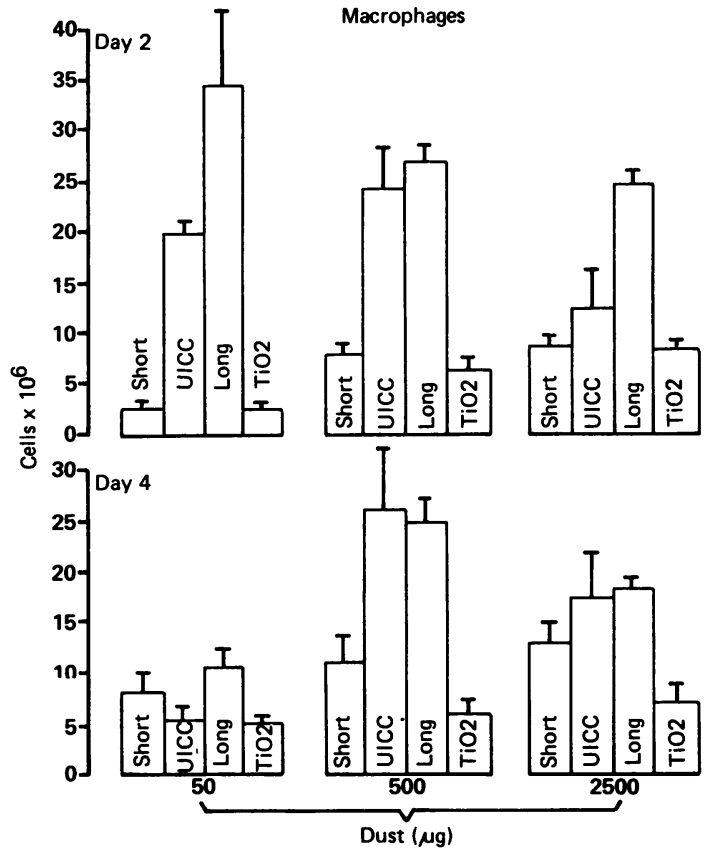

Fig 3 Numbers of macrophages lavaged from peritoneal cavity of mice injected with short amosite, long amostie, UICC amosite, or titanium dioxide at indicated doses two or four days previously.

comparisons; long, however, showed the most consistent, highly significant, increases in recruitment over $\mathrm{TiO}_{2}$, being $\mathrm{p}>0.001$ in $6 / 6$ comparisons.
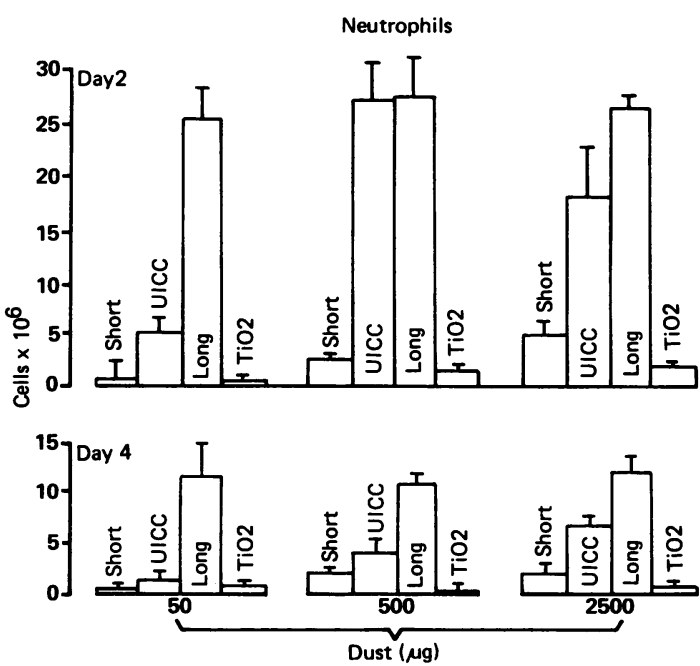

Fig 4 Number of neutrophils lavaged from peritoneal cavity of mice injected with short, long, or UICC amosite or titanium dioxide at indicated doses two or four days previously. 
Table 1 Results of comparisons between amosite asbestos samples and $\mathrm{TiO}_{2}$ in ability to cause macrophage recruitment. Significant differences relate to increases in the response with dust (a) compared with dust (b)

\begin{tabular}{|c|c|c|c|c|c|c|c|}
\hline \multirow{3}{*}{$\begin{array}{l}\text { Dust } \\
\text { (a) }\end{array}$} & \multirow[b]{3}{*}{ (b) } & \multicolumn{6}{|c|}{ Macrophages } \\
\hline & & \multicolumn{2}{|l|}{$50 \mu \mathrm{g}$} & \multicolumn{2}{|l|}{$500 \mu \mathrm{g}$} & \multicolumn{2}{|l|}{$2500 \mu \mathrm{g}$} \\
\hline & & 2 Days & 4 Days & 2 Days & 4 Days & 2 Days & 4 Days \\
\hline $\begin{array}{l}\text { Short } \\
\text { UICC } \\
\text { Long } \\
\text { UICC } \\
\text { Long } \\
\text { Long }\end{array}$ & $\begin{array}{l}\text { v } \mathrm{TiO}_{2} \\
\text { v } \mathrm{TiO}_{2} \\
\text { v } \mathrm{TiO}_{2} \\
\text { v short } \\
\text { v UICC } \\
\text { v short }\end{array}$ & $\begin{array}{l}\text { NSD } \\
\text { NSD } \\
<0.001 \\
<0.001 \\
<0.01 \\
<0.001\end{array}$ & $\begin{array}{l}\text { NSD } \\
\text { NSD } \\
\text { NSD } \\
\text { NSD } \\
\text { NSD } \\
\text { NSD }\end{array}$ & $\begin{array}{l}\text { NSD } \\
<0.001 \\
<0.001 \\
<0.01 \\
\text { NSD } \\
<0.001\end{array}$ & $\begin{array}{l}<0.05 \\
\text { NSD } \\
<0.001 \\
<0.01 \\
\text { NSD } \\
<0.01\end{array}$ & $\begin{array}{l}\text { NSD } \\
<0.001 \\
<0.001 \\
\text { NSD } \\
<0.05 \\
<0.001\end{array}$ & $\begin{array}{l}<0.05 \\
\text { NSD } \\
\text { NSD } \\
\text { NSD } \\
\text { NSD } \\
\text { NSD }\end{array}$ \\
\hline
\end{tabular}

\section{Comparisons between amosite samples}

At four days short and UICC did not, in general, significantly differ in causing inflammation (no significant differences in $5 / 6$ comparisons), although the pattern of UICC > short was consistent; at two days, however, UICC was consistently significantly more active in causing both macrophage and neutrophil recruitment than short (significant differences in $5 / 6$ comparisons). A similar pattern was evident with long v UICC with more activity of long over UICC on day 2 than on day 4 . The greatest difference was evident between long and short amosite where long was consistently highly significantly more active than short (significant differences in 10/12 comparisons).

Inflammatory potential of low dose long and short amosite asbestos

The doses used in the present study $(50,500,2500 \mu \mathrm{g})$ were those we have used previously. ${ }^{9}$ Since the inflammatory response was still evident at $50 \mu \mathrm{g}$ with long amosite, an extra experiment was carried out using $5 \mu \mathrm{g}$. The results of this, shown in table 3 , show that even at $5 \mu \mathrm{g}$ there is still a pronounced degree of inflammation with long amosite; short amosite remained virtually inactive.

\section{Macrophage spreading assay}

The macrophage spreading assay was undertaken only with cells from animals injected with the long and short amosite samples and killed four days later. While cells from animals treated with short amosite were similar to controls, the long fibre dust had produced pronounced macrophage activation $(\mathrm{p}<0.001)$ (table 4).

\section{Discussion}

This study examined the ability of long and short amosite asbestos samples to cause inflammation in the mouse peritoneal cavity; UICC amosite was included as an amosite sample whose length distribution was intermediate between the short and the long. All three asbestos samples caused significantly more inflammation than a titanium dioxide sample which we have previously found to be low in activity when administered by intraperitoneal injection, ${ }^{9}$ inhalation (K Donaldson et al, in preparation), and by intratracheal instillation (unpublished observations). The short fibre sample was closest to titanium dioxide in activity and long fibre amosite produced the greatest amount of inflammation relative to the titanium dioxide sample. There were also significant differences between the three amosite samples in their inflammation generating potential with long $>$ UICC $>$ short. At low dose $(50 \mu \mathrm{g})$ long amosite caused macrophage activation, as assessed by spreading, whereas short amosite did not.

A length of about $10 \mu \mathrm{m}$ has been found to be a key

Table 2 Results of statistical comparisons between amosite asbestos samples and $\mathrm{TiO}_{2}$. Significant differences relate to increase in the response with dust (a) compared with dust (b)

\begin{tabular}{|c|c|c|c|c|c|c|c|}
\hline \multirow{3}{*}{$\begin{array}{l}\text { Dust } \\
(a)\end{array}$} & \multirow[b]{3}{*}{ (b) } & \multicolumn{6}{|c|}{ Neutrophils } \\
\hline & & \multicolumn{2}{|l|}{$50 \mu \mathrm{g}$} & \multicolumn{2}{|l|}{$500 \mu g$} & \multicolumn{2}{|l|}{$2500 \mu \mathrm{g}$} \\
\hline & & 2 Days & 4 Days & 2 Days & 4 Days & 2 Days & 4 Days \\
\hline $\begin{array}{l}\text { Short } \\
\text { UICC } \\
\text { Long } \\
\text { UICC } \\
\text { Long } \\
\text { Long }\end{array}$ & $\begin{array}{l}\text { v } \mathrm{TiO}_{2} \\
\mathrm{v} \mathrm{TiO}_{2} \\
v \mathrm{TiO}_{2} \\
\mathrm{v} \text { short } \\
\text { v UICC } \\
\text { v short }\end{array}$ & $\begin{array}{l}\text { NSD } \\
<0.05 \\
<0.001 \\
<0.05 \\
<0.001 \\
<0.001\end{array}$ & $\begin{array}{l}\text { NSD } \\
\text { NSD } \\
<0.001 \\
\text { NSD } \\
<0.05 \\
<0.01\end{array}$ & $\begin{array}{l}<0.05 \\
<0.001 \\
<0.001 \\
<0.001 \\
\text { NSD } \\
<0.001\end{array}$ & $\begin{array}{l}<0.01 \\
\text { NSD } \\
<0.001 \\
\text { NSD } \\
\text { NSD } \\
<0.01\end{array}$ & $\begin{array}{l}<0.001 \\
<0.001 \\
<0.001 \\
<0.001 \\
<0.05 \\
<0.001\end{array}$ & $\begin{array}{l}<0.01 \\
<0.05 \\
<0.001 \\
\text { NSD } \\
\text { NSD } \\
<0.01\end{array}$ \\
\hline
\end{tabular}


Table 3 Numbers of macrophages and neutrophils recruited to the peritoneal cavity two days after intraperitoneal injection of $5 \mu \mathrm{g}$ of long or short fibre amosite. Significant difference $(p<0.001)$ between treatments

\begin{tabular}{lcr}
\hline & \multicolumn{2}{c}{ Cells $\times 10^{6}$} \\
\cline { 2 - 3 } Treatment & Macrophages & Neutrophils \\
\hline Long amosite & $23.25(3.56)^{*}$ & $13.28(3.71)$ \\
Short amosite & $4.65(0.56)$ & $0.20(0.02)$ \\
\hline
\end{tabular}

* $\mathrm{X}$ (SEM).

one in terms of the biological reactivity of fibrous dusts since fibres of this size and above are of maximal pathogenicity whereas below this length the activity begins to decrease ${ }^{1415}$; similar results are found in in vitro assays. ${ }^{4}$ In the three amosite populations used here the figure for percentage of fibres longer than $10 \mu \mathrm{m}$ was: short $0 \cdot 1-0 \cdot 2 \%$, UICC $2-3 \%$, long 10 $12 \%$. The ranking of the amosite samples in terms of their ability to cause inflammation therefore correlated with proportion of long fibres in the samples.

The short fibre amosite sample produced the lowest levels of inflammation of the three amosite samples with long amosite producing the highest. The differences between short amosite and UICC amosite, and UICC amosite and long amosite, were significant for the influx of both macrophages and neutrophils two days after injection of $50 \mu \mathrm{g}$ of dust. At higher doses, the difference between UICC amosite and long fibre amosite was less pronounced. This may be because at these doses even the UICC sample contained sufficient long fibres to produce a cell response close to the maximum for the mouse peritoneal cavity, with the additional long fibres in the long fibre sample, for this reason, having little effect. At four days after injection the macrophage response at $50 \mu \mathrm{g}$ and the neutrophils response at all doses declined considerably, similar to that found with other dusts we have examined. The reduction in macrophage influx at $50 \mu \mathrm{g}$ probably indicates that sufficient macrophages had been recruited by two days to engulf or surround all the injected fibres and to begin granuloma formation by four days with consequent reduction of the accessibility of these macrophages to the lavage techniques

Table 4 Macrophage spreading on glass after injection of $50 \mu \mathrm{g}$ of dust four days previously. Significant differences $(p<0.001)$ between long amosite and the other two treatments

\begin{tabular}{ll}
\hline Treatment & Macrophage spreading ( $\mu m)$ \\
\hline Saline control & $10.90(1.93)^{*}$ \\
Long amosite & $17.38(7.08)$ \\
Short amosite & $10.93(5.01)$ \\
\hline
\end{tabular}

* 8 (SD). used. At the two higher doses, levels of macrophage recruitment remained at similar levels between two and four days. This may imply that sufficient free dust had remained over this period, or that there was sufficient tissue damage, to keep recruitment high even though "fixing" of cells by early granuloma formation would have been taking place.

The results described here are complementary to those published ${ }^{3}$ using the same long and short amosite samples. In that study the long fibre sample was much more fibrogenic than the short and caused more long tumours. We have shown here that the increased ability to produce injury and inflammation in vivo, shown by the long fibre sample, is consistent with the increased pathogenic potential of the same sample. ${ }^{3}$ We are aware of only one previous study relating asbestos fibre length to inflammatory potential $^{16}$; this showed similar results to those described here with long fibres being much more active. In that study, however, chrysotile from two different sources was used; unlike the present study which used a long fibre sample and a short fibre sample prepared from it so excluding the potential for differences in asbestos composition in the two samples. We have also shown the effect across a range of doses and shown that, even at $5 \mu \mathrm{g}$ per mouse, the long fibre sample is intensely active in causing inflammation while even at $2500 \mu \mathrm{g}$ the short fibre sample is low in activity.

Evidence of a link between inflammation in the alveolar region of the lung and development of pulmonary fibrosis has come from many studies in different fibrotic lung disease. ${ }^{6}$ In the case of mineral dust related fibrosis there is compelling evidence that fibrogenic dusts cause pulmonary inflammation in occupationally exposed men, ${ }^{178}$ and experimentally exposed animals. ${ }^{819}$ Inflammatory leucocytes have the potential to cause damage to the fragile lung parenchyma through release of oxidants and proteases, ${ }^{5}$ which may lead to a repair response and fibrosis if damage is sufficiently great. Macrophages also possess the ability to stimulate fibroblast growth and this is increased in activated macrophages ${ }^{20}$ such as those found in inflammatory sites and in macrophages from lungs exposed to toxic dust. ${ }^{16}$ Inflammation may also play a part in tumorigenesis in the case of fibrous dusts such as asbestos. Here the genotoxic effects of asbes$\operatorname{tos}^{21}$ combined with a generalised "promoting" effect during the proliferative phase of inflammation could favour neoplastic change. ${ }^{22}$

\section{References}

1 Seaton A. Asbestos-related diseases. In: Morgan WKC, Seaton A, eds. Occupational lung diseases. Philadelphia: Saunders 1984:323-76. 
2 Davis JMG. Current concepts in asbestos fiber pathogenicity. In: Lemen R, Dement JM, eds. Dusts and disease. Illinois: Pathotox Pub, 1979:45-9.

3 Davis JMG. The pathogenicity of long versus short fibre samples of amosite asbestos administered to rats by inhalation and intraperitoneal injection. Br J Exp Pathol 1986;67:415-30.

4 Brown GM, Cowie H, Davis JMG, Donaldson K. In vitro assays for detecting carcinogenic mineral fibres: a comparison of two assays and the role of fibre size. Carcinogenesis 1986;7:1971-4.

5 Fantone JC, Ward P. Pathogenesis of the granulomatous lung diseases. Part III. Mechanisms of lung parenchymal injury. Am Rev Respir Dis 1984;130:484-91.

6 Keogh BA, Crystal RG. Alveolitis-the key to the interstitial lung disorders. Thorax 1982;37:1-10.

7 Janoff A, White R, Carp A, Harel S, Dearing R, Lee D. Lung injury induced by leukocytic proteases. Am J Pathol 1979;97:111-36.

8 Begin R, Rola-Pleszcynski M, Masse S, Nadeau D, Drapeau G. Assessment of progression of asbestosis in the sheep model by bronchoalveolar lavage and pulmonary function tests. Thorax 1983;38:449-57.

9 Donaldson K, Bolton RE, Brown D. Inflammatory cell recruitment as a measure of mineral dust toxicity. Ann Occup Hyg (in press).

10 Davis JMG, Beckett ST, Bolton RE, Collings P, Middleton AP. Mass and number of fibres in the pathogenesis of asbestosrelated lung disease in rats. Br J Cancer 1978;37:673-88.

11 Timbrell V. Characteristics of the International Union against Cancer standard reference samples of asbestos. In: Shapiro HA, ed. Pneumoconiosis: proceedings of the international conference, Johannesburg, 1968. Oxford: Oxford University Press, 1969: 28-36.

12 Donaldson K, Bolton RE, Brown D, Douglas AN. An improved macrophage spreading assay; a simple and effective measure of activation. Immunological Communications 1984;13:229-44.

13 Snedecor GW, Cochran WG. Statistical methods. Iowa State University Press, 1980.

14 Stanton MF, Wrench C. Mechanisms of mesothelioma induction with asbestos and fibrous glass. J Natl Cancer Inst 1972;48: 782-97.

15 Davis JMG. The use of animal model for studies on asbestos bioeffects. Ann NY Acad Sci 1979;330:795-8.

16 Lemaire I, Beaudoin H, Dubois C. Cytokine regulation of lung fibroblast proliferation. Pulmonary and systemic changes in asbestos-induced pulmonary fibrosis. Am Rev Respir Dis 1986;134:653-8.

17 Voisin C, Wallaert B, Aerts C, Grosbois JM. Bronchoalveolar lavage in coalworkers pneumoconiosis: oxidant and antioxidant activities of alveolar macrophages. In: Beck EG, Bignon J, eds. In vitro effects of mineral dusts. Berlin: SpringerVerlag, 1985;93-100.

18 Gellert AR, Langford JA, Winter RJD, Uthayakumar S, Sinha G, Rudd RM. Asbestosis: assessment by bronchoalveolar lavage and measurement of pulmonary epithelial permeability. Thorax 1985;40:508-14.

19 Martin TR, Chi EY, Covert DS, et al. Comparative effects of inhaled volcanic ash and quartz in rats. Am Rev Respir Dis 1983;128:144-52.

20 Martin RM, Gimbrone MA, Unanue ER, Cotran RS. Stimulation of non-lymphoid mesenchymal cell proliferation by $D$ macrophage-derived growth factor. J Immunol 1981;126: 1510-5.

21 Mossman BT, Craighead JE. Mechanisms of asbestos carcinogenesis. Environ Res 1981;25:269-80.

22 Sporn MB, Roberts AB. Peptide growth factors, and inflammation, tissue repair and cancer. $J$ Clin Invest 1986;78:329-32.

\section{Vancouver style}

All manuscripts submitted to the $\mathrm{Br} J$ Ind Med should conform to the uniform requirements for manuscripts submitted to biomedical journals (known as the Vancouver style)

The $\mathrm{Br} J$ Ind Med, together with many other international biomedical journals, has agreed to accept articles prepared in accordance with the Vancouver style. The style (described in full in $\mathrm{Br}$ Med J, 24 February 1979, p 532) is intended to standardise requirements for authors.

References should be numbered consecutively in the order in which they are first mentioned in the text by Arabic numerals above the line on each occasion the reference is cited (Manson ${ }^{1}$ confirmed other reports ${ }^{2-5} \ldots$.). In future references to papers submitted to the $\mathrm{Br} J$ Ind Med should include: the names of all authors if there are six or less or, if there are more, the first three followed by et al; the title of journal articles or book chapters; the titles of journals abbreviated according to the style of Index Medicus; and the first and final page numbers of the article or chapter.

Examples of common forms of references are:

I International Steering Committee of Medical Editors. Uniform requirements for manuscripts submitted to biomedical journals. Br Med J 1979;1:532-5.

2 Soter NA, Wasserman SI, Austen KF. Cold urticaria: release into the circulation of histamine and eosino-phil chemotactic factor of anaphylaxis during cold challenge. $N$ Engl J Med 1976;294:687-90.

3 Weinstein L, Swartz MN. Pathogenic properties of invading micro-organisms. In: Sodeman WA Jr, Sodeman WA, eds. Pathologic physiology: mechanisms of disease. Philadelphia: W B Saunders, 1974:457-72. 